\title{
NONO wt Allele
}

National Cancer Institute

\section{Source}

National Cancer Institute. NONO wt Allele. NCI Thesaurus. Code C71420.

Human NONO wild-type allele is located in the vicinity of Xq13.1 and is approximately 18 $\mathrm{kb}$ in length. This allele, which encodes non-POU domain containing, octamer-binding protein, may play a role in the mediation of transcription, RNA splicing and DNA secondary structure. The gene can be involved in an inversion inv $(X)(p 11.2 ; q 12)$ with the TFE3 gene in some papillary renal cell carcinomas. 